\title{
Translating the Jump of a Horse - two translations of Federico García Lorca's Poeta en Nueva York
}

\author{
Nanna Holm
}

This article deals with metaphor translation emphasising the common ground between translation theory and Cognitive Linguistics (CL). Within the framework of CL, a comparative study of two Danish translations of Spanish poet Federico García Lorca's 'Poeta en Nueva York' is presented, focusing on a selection of metaphors that form networks throughout the work in question. It is then analysed if and how these metaphoric networks have been successfully transferred into the target language (TL). In conclusion, some remarks are made on the contribution of CL to the overall discussion of the translatability of metaphors.

\section{Lorca's poetics}

The title of the present article is an expression from Federico García Lorca himself. It is taken from the essay (originally a lecture) La imagen poética de don Luís Góngora (Lorca 1965:69), which is both a homage to Spanish Baroque poet Góngora and his use of metaphor aesthetics and an expression of Lorca's own view of metaphors. In it, Lorca defines the term metaphor metaphorically, saying that

La metáfora une dos mundos antagónicos por medio de un salto ecuestre que da la imaginación. El cinematográfico Jean Epstein dice que "es un teorema en que se salte sin intermediario desde la hipótesis a la conclusión". Exactamente.

A metaphor is defined as a leap, "a jump of a horse", between two opposite worlds that the human imagination must make. Consequently, poetry (and Góngora's metaphors in particular) in Lorca's view rely on the ability to present or organise the two different worlds, or, in Lorca's words "shape the landscapes" ("ordenar los paisajes").

Lorca seems to believe that metaphors are first and foremost based in the human senses: "Un poeta tiene que ser profesor en los cinco sentidos corporales" (Lorca 1965:67). This can be said to be Lorca's synaesthetic credo, so to speak. Synaesthetic metaphors are by far the most frequent in Poeta en Nueva York.

Lorca also states that metaphors exist in everyday language saying that "El lenguaje está hecho a base de imágenes, y nuestro pueblo tiene una riqueza magnífica en ellas" (Lorca 1965:62).

Lorca situates metaphors within the human imagination and thus does not seem inclined to propose a traditional definition of metaphor, i.e. an exclusively - if necessary, dispensable - ornament. His perception of 
metaphors seems to be closer to the one found in CL, and so is the notion that language is based on images (cf. metaphors are defined as generic within CL) as well as the discovery that metaphor is present in everyday language, and not exclusively in poetry. Lorca does not explicitly refer to the term domains, but uses the word paisajes. He seems to be aware of the role that domains play in the production of metaphors.

Lorca's definition of metaphor makes for a very interesting starting point to an analysis of his poems. When it comes to translating metaphors, it is also useful to keep Lorca's definition in mind. Indeed, the difficulty - one might even say impossibility - of translating metaphors (in Lorca's own terms, translating the jump of the horse) has often been pointed out and analysed, both within linguistics and translation theory (Newmark 1985; Dagut 1976, 1987). Metaphors are often mentioned as one of the main stumbling blocks or obstacles for translating, and in particular translating poetry. This mainly because poetry is considered a genre with a very high metaphor density.

The difficulties in translating metaphors make the translator's limitations stand out. This has made many consider the translation of metaphors paradigmatic for translation as such, and the (im)possibility of translation in general (e.g. Mason 1982; van den Broeck 1981). At the very least it is recognised within the field of translation that metaphors constitute a special phenomenon that requires special translation strategies. In addition, the translation process can be seen as a metaphoric activity; when translating, we transfer meaning from one language into the other, and are always situated in the leap or jump between the two languages in question.

\section{Translation and Cognitive Linguistics (CL)}

In CL, a metaphor is defined as a mapping (transference) between two domains.

In working with Lorca's metaphors in Poeta in Nueva York, I found CL useful for assessing that most of the prevalent metaphors in this collection are not single, isolated phenomena, but form networks. As Stienstra (1993) states:

If we want to discuss the translatability of metaphor at a more advanced level than that of the individual example, we will have to show ourselves aware of the fact that many, if not most, interesting metaphors form networks which are both systemic and dynamic. It is only by investigating whether such a network can be transferred into another language, that we can make progress in answering the question as to the translatability of metaphor. (215)

I believe this view and analysis of metaphor provides a method for a more coherent analysis of the metaphors in a given text/poem (or in this case, an entire collection of poems), and this was my point of departure for the analysis presented here. 
Tabakowska (1993) believes that CL is able to provide the framework for a more adequate assessment of equivalence and is an instrument to describe, compare and evaluate the ways in which a given pair of languages structure their semantic contents.

This way, CL may provide answers to, for example, the question why some metaphors are more easily translatable than others, thus opening the possibilities for a step forward from the traditional impossible-no problempositioning. As Mounin (1963:273) has pointed out, translatability is relative, but relative within certain limits, to certain degrees. It is these "certain limits" that CL can help to determine and describe.

A development of translation strategies within the framework of CL does not so much rely upon the question of whether and how closely SL and TL are related, but rather how much the languages in question share experiential realities. The process of translation might in this case help to provide an understanding of the culture behind the SL text; or, in any case, a possible view of how both SL and TL speakers organise their background knowledge.

Alexieva (1997) states that it is important for the translation process (and, consequently, for achieving and assessing equivalence) to analyse the organisation of the domains involved. According to Alexieva, difficulties in translating metaphors arise not so much or not always because of the occurrence of metaphors per se, but in a possible difference in domain structuring between SL and TL. This difference may be due to the fact that the two cultures involved organise their background knowledge differently, or to the fact that a given author works with a highly specific or idiosyncratic organisation of domains (which is often the case in poetry). This way, differences across languages and cultures can first and foremost be identified in the internal structuring of the various domains, and in the domains' interconnectedness, their stability and internal structuring (141).

By investigating how the semantic domains are structured, it is perhaps possible to achieve a more equivalent translation or, at least, a better understanding of the SL text.

The cognitive translation hypothesis is based on 2 premises (Mandelblit 1995:487):

- It is assumed that the goal of translation is communicative or dynamic equivalence rather than formal equivalence (as defined by Nida 1964:159). In other words, when metaphoric expressions are translated, the goal is not necessarily to transfer the exact vocabulary from SL into TL, but rather to find an expression in TL which corresponds to the expression in SL.

- It is assumed that translation is possible in the sense that human beings are capable of conceptualising categories in language(s) other than their mother tongues, and that translators are indeed capable of transferring meaning from one language into another, using this capacity.

If metaphors are cognitive and not exclusively an ornamental phenomenon, it must be assumed that one of the main causes for difficulty in translating 
them consists in the fact that there is no automatic similarity between the metaphor systems of SL and TL. If both languages use different mappings to express the same meaning, and these mappings are conceptual and not merely ornamental, then translation consists of a transfer, not just from one language into another, but also from one conceptualisation into another. This occurs in two different scenarios:

- In SL there is a metaphoric mapping from one given domain (D2) to another (D1). Speakers of SL partly conceptualise D1 by way of inventory from D2. This domain mapping will result in linguistic expressions in SL.

In TL the same domain mapping occurs, so it is not necessary for the translator to shift conceptually. Since SL and TL use the same mapping, this is usually called Similar Mapping Condition (SMC). These cases can further be divided into cases where the expression in TL is almost the same as in SL using the same vocabulary, and cases where the metaphoric mappings are similar, but the vocabulary is different.

- The two languages use different metaphoric mappings to express the same meaning: In SL, D2 is still mapped onto D1 as described above. In TL the case is that a third domain, D3, is mapped onto D1 (alone or in combination with D2). The translator is obliged to shift conceptually when transporting the metaphor to TL. This is called a Different Mapping Condition (DMC).

According to Mandelblit, difficulties in the translation process may arise because of the fact that the translator is locked - fixed - in SL's metaphoric system and thus not capable of shifting to TL's metaphoric system.

My own analysis suggests (tentatively, I should emphasise) that at least as far as the translations of Poeta en Nueva York are concerned, there has in several cases been a fixation on the TL metaphoric system as well (see 3.4.).

\section{Metaphors in Poeta en Nueva York}

\subsection{Poeta en Nueva York and the Danish translations}

Poeta en Nueva York was created during the author's stay in the USA and Cuba in the period 1929-30. After Lorca's death, the collection was constructed on the basis of partial publications in various reviews and anthologies, and parts of the author's unpublished manuscripts. The reconstructed collection was first published in $1940^{1}$.

Poeta en Nueva York has been translated and published in two Danish editions; one by Peter Lau (1975; translator 1) and one by Peer Sibast (1983; translator 2). It is obvious in comparing the two translations that the translators have not used the exact same edition of the SL text. In the present ar- 
ticle, I will refrain from further elaborating on the extensive manuscript problems. Where the Danish vocabulary is translated into English, the translations are my own.

\subsection{Domains in the Spanish poems}

I used a very tentative, common-sense categorisation of the domains in the analysis that I carried out. Some domains are vast and were further subdivided. In alphabetical order:

Animals / Body parts / City / Clothing / Death / Dryness / Earth / Feelings - Emotions / House / Human beings - Persons / Land - Countryside / Love / Meteorology / Minerals / Money / Plants / Religion Bible / Science - Technology / Senses / Sky / Violence - Mutilation / Water / Weapons

\subsection{The global metaphors}

The term global metaphors refers in this article to metaphors prevalent throughout Poeta en Nueva York, i.e. present in more than one poem and governing several metaphoric expressions. A selection of the global metaphors found in the collection is presented below.

Most metaphors in the collection are indeed a true "jump of the horse" in the sense that they unite two opposed concepts or worlds (cf. Lorca's definition of metaphors in paragraph 1 above). Some examples are "panorama ciego", "mi hueco traspasado", "el aire duro", "las alegres fiebres", "las barcas de los cementerios", "una cápsula de aire donde nos duele todo el mundo", "las muchedumbres en el alfiler", "el hueco de una hormiga puede llenar el aire", "toda la luz del mundo cabe dentro de un ojo", "el campo de todo un lustro cabrá en la mejilla de la moneda", "llenaban los muros con un solo corazón de paloma" and "pequeño poema infinito".

3.3.1. Some of the global metaphors are well-known global metaphors as identified by Lakoff and Turner (1989). It is characteristic that many of these global metaphors are inverted, so to speak. For example, PEOPLE ARE PLANTS is inverted and becomes PLANTS ARE PEOPLE/LIVING BEINGS. Similarly, the global metaphor LIFE IS FLUID is inverted in the global metaphor DRINKING ALCOHOL IS DRINKING DEATH. Consider the following:

In several poems ("Cielo vivo", "Cementerio judío" and "Crucifixión") the expressions draw on the conceptual metaphor FEELINGS ARE TEMPERATURE, closely related to another metaphor, LIFE IS FIRE". Examples are "la escarcha de los ojos apagados" and "salieron los fríos cantando". Both translators have been able to transfer the expressions with similar mappings in all cases, possibly because LIFE IS FIRE is one of the more universal conceptual metaphors. 


\section{DEATH IS LANDSCAPE}

This metaphor draws upon DEATH IS THE END OF LIFE'S JOURNEY ${ }^{3}$, which in turn is derived from LIFE IS A JOURNEY ("mi muerte desierta con un solo paseante equivocado").

Part of this metaphoric network is LIFE IS SAILING. It has some very idiosyncratic expressions created by Lorca in this particular case, but interestingly enough, both translators have transferred these expressions very successfully and with similar mappings. I believe that this is because LIFE IS SAILING is a conceptual metaphor which is very prevalent in Danish.

\section{PEOPLE ARE PLANTS 5 .}

$\rightarrow$ SCREAMS ARE PLANTS ("las raicillas del grito")

$\rightarrow$ LONELINESS IS DROUGHT. This metaphor is strongly interconnected with the opposite, WATER IS ALIVE/LIFE IS FLUID, see below. An example is "marchita soledad". Both translators have been able to transfer this metaphor successfully throughout. I believe this allows for the cautious conclusion that the more the global metaphor enters into a network with others (here WATER IS ALIVE/LIFE IS FLUID), the easier it seems to be for the translator to identify it and consciously try to transfer it into TL.

\section{Plants ARE BEINGS}

$\rightarrow$ TREES ARE BEINGS. In most cases, the translators have been able to transfer this metaphor. One particularly idiosyncratic exception is "el árbol de muñones", which is a mapping of the plant domain and the body part domain. Both translators have failed to identify that there are two domains involved, thus translating the metaphor with a TL wording that stays in one domain ('grenstump' and 'træstubben', respectively, which in TL are different parts of a tree).

$\rightarrow$ GRASS IS A BEING ("el diminuto griterío de las hierbas") is transferred with similar mappings.

NIGHT IS SPACE is a metaphor drawing on TIME IS SPACE ("tenía la noche una hendidura"). This metaphor has been transferred into TL with similar mappings.

WATER IS ALIVE draws on LIFE IS FLUID” ("El agua duerme una hora/y el mar blanco duerme cien").

$\rightarrow$ RAIN IS A BEING ("deambulan intactas las lluvias bailarinas").

$\rightarrow$ THE RIVER IS A BEING ("el río que viene cantando", "el Hudson se emborracha"). This metaphor has an inverted counterpart: THE "I" IS A RIVER ("Mira qué orillas tengo de jacintos!")

$\rightarrow$ THE SEA IS A BEING ("el mar ahogado en la arena")

Other global metaphors also drawing on LIFE IS FLUID are BLOOD IS ALIVE, SALVATION IS WATER ("Cristo puede dar agua todavía") and FEELINGS ARE LIQUID. Generally speaking, the translators have used the same mappings in TL without any apparent difficulty. 
3.2.2. An extensive number of the global metaphors are personifications or animations:

THE BODY IS GLOBE

$\rightarrow$ THE BODY IS A PASTURE / A PIECE OF LAND ("el espeso musgo de mis seines")

$\rightarrow$ BLOOD IS A SEA ("el desembarcadero de la sangre", "naufragio de sangre")

$\rightarrow$ EYES ARE A LAKE / A SEA ("lloras por las orillas de un ojo de caballo")

$\rightarrow$ THE TONGUE IS A PIECE OF LAND ("manar rosas de nuestras lenguas")

$\rightarrow$ THE HEART IS A HARBOUR ("las barcas de nieve se agolparon/por las escalerillas de su corazón”)

$\rightarrow$ THE HEART IS A FIELD ("las hierbas de mi corazón")

This metaphor also has an inverted counterpart, THE EARTH IS A BEING

$\rightarrow$ THE LANDSCAPE IS A BODY ("en el pecho de los paisajes")

$\rightarrow$ MounTAINS ARE BEINGS ("los montes todavía no respiran")

All of these have been translated into TL with similar SL mappings.

These global metaphors enter into networks with the following:

THE SKY IS A BEING ("el cielo pudo desnudarse")

THE MOON IS A BEING (see below)

WINDS ARE BEINGS ("viajero por su propio torso blanco./Así iba el aire")

CLOUdS ARE BEINGS ("las nubes en manada/se quedaron dormidas")

These must be said to be ontological metaphors present not only in Lorca's works, but probably close to being universal in art and literature. In this particular work however, Lorca gives them some special extensions, e.g. "la luna les azota", "la luna tiene un sueño", and "las nubes en manada/se quedaron dormidas". As is well-known, Lorca's animation/personification of the moon is omnipresent in his works. Awareness of this has probably helped the translators to find similar TL mappings.

3.3.3. Others are what could be called conceptual metaphors at a microlevel:

THE CHURCH IS A SHIP (“en el centro de la misa yo romperé el timón”). This metaphor is used in many languages, cf. English nave. Indeed, in TL the nave is called kirkeskib (literally 'church ship'). For this reason, the translators have not had difficulties in translating even very particular expressions derived from this metaphor. The close relation with LIFE IS A SALING may be another reason for what seems to have been a successful transfer into TL.

LOVE IS A BUILDING. This metaphor is probably not only found in Lorca's works, but he gives it a particular extension. 
TENDERNESS IS COVERING WITH A ROOF ("los tejados del amor", "has venido, amor mío, a cubrir mi tejado")

These metaphors have been transferred into TL with similar SL mappings.

LOVE IS A FRUIT (“amores cubiertos de gusanos”)

LOVE IS A PLANT ("ternura desgranada")

These metaphors are probably not specific to Lorca's poetry, and perhaps for this reason, the translators have been able to transfer them with similar SL mappings.

3.3.4. Yet other global metaphors are more idiosyncratic or particular metaphors. The following metaphors seem to be highly specific to this collection:

MONEY IS PRESSURE ("el manómetro que mide el cruel silencio de la moneda")

MONEY IS (DANGEROUS) WEATHER CONDITIONS ("huracanes de oro")

MONEY IS INTOXICATING ("los borrachos de plata") - this in turn relates money to death by way of DRINKING ALCOHOL IS DRINKING DEATH (“donde meriendan muerte los borrachos").

Both translators have apparently been able to identify the domains used in these metaphors, and have thus transferred them with similar SL mappings.

While the translators in most cases have been able to identify the domains in question, and consequently to transfer them into TL, the transfer of specific inventory of the domains seems to have been more difficult.

\subsection{Transfer of the domains' inventory into TL}

As far as the animal domain is concerned, the translators have in every case been able to choose vocabulary from this domain even though they have in some cases not been able to identify the exact content in the animal domain.

The choice of words in the metaphoric expressions may not in every case be similar to the one used in SL, but the translators have had no difficulty staying within the same domain. An example: Translator 1 has translated avispas with 'bier' ('bees') and translator 2 has translated this with 'hvepse' ('wasps'). I believe that this is due to the fact that the animal domain is one of the most ample (vast) and varied in this collection of poems. The inventory from this domain is active in animations or anthropomorphisms such as "bebían agua por las fuentes los abanicos y los aplausos", "la ovilla busca (...) su ansia de longitud insatisfecha", "barcos mudos", "la aurora gime", "cojos perros fumaban sus pipas", "el plomo era un colibrí", and "orugas parlantes".

The same thing seems to be the case for the plant domains; since these domains are very varied, the translators have easily been able to stay within the domain in TL, even though they have not chosen the formal equivalent 
vocabulary in each particular case. For example, in the poem "Luna y panorama de los insectos", translator 1 has translated the word dalias (dahlias) with 'vinstokke' ('vines'), which cannot be said to be an equivalent wording, but nevertheless is from a similar TL domain.

As far as the water domain is concerned, the translators do not seem to have had any difficulty in achieving semantic distribution which is just as varied in TL as in SL - probably because there is a rich variety of expressions which employ this domain in TL and which can be activated without any difficulty. The dry domain has not caused problems for the translators either, presumably because this domain can easily be identified.

The same applies to the earth domain: both translators have in several cases chosen different vocabulary for the particular wordings, e.g. the Spanish word fango, which is translated somewhat randomly with the words 'dynd' ('mud') or 'smuds' ('filth'). The choice of words, however, remains one from the earth domain. An exception is cenizas, which translator 1 has translated with 'gløder' ('embers'), an expression from outside the earth domain.

Such is also the case for the weapons domain: in general, the translators have used a similar TL domain. The only exception is the word alfiler, which in its turn is the most frequently used element from this domain. It has been translated somewhat randomly with 'nål' ('needle') and 'kniv'('knife') - in other words, the translators have chosen vocabulary from the same domain even though the specific choice of words varies.

Interestingly enough, the sense domains (colours, light/darkness, sound, touch, taste) seem to force the translators to choose not only similar domains, but similar vocabulary. This is to be expected, as the sense domains and their inventory are probably rather universal and easily identifiable in both SL and TL.

The way in which Lorca combines the sense domains is however very specific. The sense domains are used in the synaesthetic metaphors which are abundant, probably the most frequent in the poems. In these expressions, inventory from two (in some cases three) sense domains are combined. Some key examples are: "azul crujiente", "calor blanco", "todo rumor será piedra y toda huella, latido", "al loco unisón de la luz", "gemidos que golpean" and "alarido blanco".

With few exceptions, the translators have managed to use similar mappings in TL for the synaesthetic metaphors. In the poem "Nacimiento de Cristo", translator 2 has translated "linternas sordas" with "dæmpede lys' ('dimmed lights'), a DMC which does not activate more than one domain and thus does not produce the equivalent synaesthetic effect in TL. Translator 1 has translated the expression with "døve lanterner", ('deaf lanterns'), thereby transferring both the synaesthesia and the animation.

The body domain, however, is different. Both translators have in several instances translated with TL vocabulary different from SL vocabulary, even though a similar TL vocabulary is available in translating expressions involving inventory from this domain. This is rather unexpected, since if there are any cross-cultural and universal domains, the body domain 
should be one of them. I believe that this is due to the fact that body parts enter into various idiomatic expressions in SL as well as in TL, and that this fixation on either SL or TL affects on the translation or impedes a choice of similar vocabulary. In the poem "1910 - Intermedio", for example, translator 1 has translated the SL verse "El seno traspasado de Santa Rosa dormida" with 'den sovende Santa Rosas gennemborede skød' ('sleeping Saint Rosa's pierced womb'). But an equivalent choice of vocabulary for seno would be 'bryst' in TL ('bosom'). The image invoked is the quite common dolorosa figure (the Virgin Mary or other female saints), often depicted with the breast pierced by knives or swords to symbolise their suffering and pain. What seems to have motivated translator 1's choice of words is the Spanish idiomatic expression el seno de la familia (the Danish equivalent idiom is $i$ familiens sk $\phi d$ (literally: 'in the family's womb/lap'). This is an example of an SMC with different choice of words. Both SL and TL have the conceptual metaphor THE FAMILY IS A BODY, but the idiomatic expressions use different vocabulary (different body parts). Translator 1 has been motivated by this SMC, and by a fixation on TL, to translate seno with 'skød' regardless. Perhaps in this case, a lack of knowledge of the dolorosa figure (less usual outside a Catholic context) also plays a part. Translator 2 has chosen the more similar word, 'bryst'.

In the poem "Fábula y rueda de los tres amigos" the same process is repeated; seno has been translated with 'skød' by translator 1 and with 'bryst' by translator 2 . Thus, it is possible to conclude that a fixation on TL can in some cases hinder the translation of specific vocabulary even though the domain inventories may be very similar in SL and TL. This might then allow us to view equivalence as a matter of degree; a higher degree of equivalence may be obtained by using a similar domain and the similar inventory (SMC with similar vocabulary) rather than using only the similar domain (SMC with different vocabulary).

In translating single items from the body domain, both translators have in certain cases been strangely inconsequent in their choice of vocabulary; e.g. the word "cintura" has been translated randomly; it seems, with 'talje' ('waist'), 'midje' (waistline), 'liv' (waist) and 'bælte' ('belt') - the latter is a change of domain (shifting to the clothes domain). The word "desnudo" has been translated interchangeably with 'nøgen' ("nude'), 'nøgenhed' ('nudity') and with the more free, metaphorically motivated 'uhæmmet' ('unbridled').

The religious/biblical domain apparently presents great difficulty for the translators - but this cannot be because the domains are unknown, differently organised or nonexistent in TL. Quite the contrary, this should indeed be a case where SL and TL share cultural references and experiential realities. Nevertheless, there seem to have been difficulties, possibly because it takes some effort to identify the inventory as belonging to this particular domain. Two significant examples:

1) In the poem "Danza de la muerte", translator 1 has translated the metaphor "la espiga en el ojo" with 'tornen i øjet' (literally: "the thorn in the eye'). Translator 2 has translated it with the more equivalent expression 
'akset i øjet' ('spike in the eye'). It is very possible that translator 1 has misread the word (espina in stead of espiga), and consequently thought that the metaphor in question was a Spanish idiom equivalent to the Danish idiom "torn i øjet". And it is true that SL and TL share the conceptual metaphor DIFFICULTIES IN LIFE ARE IRRITATIONS ON THE BODY, which in Danish results in the idiom mentioned above. However, this is not the metaphor activated here: there is no Spanish idiom with the wording "la espiga en el ojo". Instead, this expression is probably a rather subtle derivation from the biblical metaphoric expression "ver la paja en el ojo ajeno (y no la viga en el propio)". This is not a metaphorisation of difficulties, but of self-righteousness or hypocrisy. Before a part of a plant becomes paja, it is: espiga; hence possibly the expression "la espiga en el ojo".

2) In "Crucifixión" both translators have apparently failed to identify the biblical origin of the expression "un camello blanco/que lloraba porque al alba/tenía que pasar por el ojo de una aguja". This is an expression used in daily speech in many languages, signifying something that seems completely impossible. In this poem, Lorca re-activates the expression - someone is actually forcing the camel to pass through the proverbial eye of the needle. Both translators have a DMC and thus have been able to transfer only the anthropomorphism of the camel: translator 1 has translated with 'en hvid $\mathrm{kamel} / \mathrm{som}$ græd fordi den var nødt til/at presse morgengryet gennem et nåleøje' (a white camel, crying because it had to/push the dawn through the eye of a needle'), and translator 2 has translated it with 'en hvid kamel som græd/fordi morgengryet/uundgåeligt måtte igennem et nåleøje' ('a white camel, crying/because the dawn/inevitably had to pass through the eye of a needle').

Thus the common reference (be it the Bible or simply every day speech) is not reproduced, and, most importantly, not re-activated in TL. This makes for a translation that is less equivalent than it could have been. Perhaps the explanation is to be found in the fact that the domain of religion/bible has a rather weak interconnectedness with other domains; in other words, it might have been difficult for the translators to identify when this particular domain was in use. This lack of domain identification seems to have been a general cause for difficulty in the translation, as well as cases where the translator has misread or misunderstood the text in ways which have then prompted a domain shift in TL. Mix-ups of domains seem to have motivated misunderstandings of specific SL vocabulary on the translator's part.

I believe the examples of the two Danish translations of Lorca's poems that I analysed show that a higher degree of consciousness of the metaphoric networks might have helped the translators to translate in a more equivalent way than was actually the case (i.e. if the translator is working only on intuition or on a word-for-word basis). I also believe that CL provides a better possibility for assessing not just whether a given translation of a metaphor can be said to provide the equivalent effect in TL or not, but what this effect consists of and through which criteria equivalence can be achieved. 


\section{Concluding remarks}

It should be possible to tentatively conclude that CL can contribute to the more overall discussion of translatability of metaphors as such (and perhaps translatability in general, since the translation of metaphors is viewed by many as paradigmatic for translation activity and/or the (im)possibility of translation in general). By means of analysing the complexity of a given mapping or set of mappings, it becomes possible to view equivalence, and perhaps, translatability, as a matter of degree, as it were.

If metaphors are not universal - as in universally present - it would mean that some languages or cultures are able to express themselves metaphorically, while others are not. This would of course entail that translation between these languages - and perhaps translation in general - would be impossible.

However, CL claims that the human mind is metaphoric in nature (which is the same as saying that metaphors are universal), and, at the same time, that metaphors may very well be culturally specific. In this way, in working with on translation within the framework of CL, it is not assumed or claimed that translation is a priori impossible, nor that it is possible in every conceivable circumstance.

Finally, I believe that CL might ideally grant translators - and others - an increased knowledge and understanding of how the background knowledge and conceptualisations of different languages and cultures are prompted, and thereby hopefully contribute to a higher degree of consciousness on how to mediate these differences.

\section{Bibliography}

Alexieva, Bistra (1997). "There Must Be Some System In This Madness - Metaphor, Polysemy and Wordplay in a Cognitive Linguistics Framework." Dirk Delabastita (ed.) (1997). Traductio: Essays on Punning and Translation. Manchester: St. Jerome, 137-154.

Broeck, Raymond van den (1981). "The Limits of Translatability Exemplified by Metaphor Translation." Poetics Today 2(4), 73-87.

Dagut, Menachem (1976). “Can Metaphor Be Translated?" Babel 22(1), 21-33.

Dagut, Menachem (1987). "More About the Translatability of Metaphor." Babel 33(2), 77-84.

Fauconnier, Gilles (1997). Mappings in Thought and Language. Cambridge: Cambridge University Press.

García-Posada, Miguel (1981). LORCA: Interpretación de "Poeta en Nueva York". Madrid: Akal

Lakoff, George \& Mark Johnson (1980). Metaphors We Live By. Chicago/London: University of Chicago Press.

Lakoff, George (1987). Women, Fire, and Dangerous Things - What Categories Reveal about the Mind. Chicago/London: The University of Chicago Press.

Lakoff, George \& Mark Turner (1989). More than Cool Reason. A Field Guide to Poetic Metaphor. Chicago/London: University of Chicago Press.

Lorca, Federico García (1998/1940). Poeta en Nueva York. Madrid: Cátedra.

Lorca, Federico García (1965). "La imagen poética de don Luís de Góngora." 
Federico García Lorca ( $\left.{ }^{9} 1965\right)$. Obras Completas. Madrid: Aguilar, 62-85.

Lorca, Federico García (1975). Digter i New York (tr. Peter Lau). Århus: Husets Editorial/Translated Literature Society.

Lorca, Federico García (1983). Digter i New York (tr. Peer Sibast) (ill. Bjørn Nørgaard). Brøndums Editorial.

Mandelblit, Nili (1996). "The cognitive view of metaphor and its implications for translation theory." Marcel Thelen \& Barbara Lewandowska-Tomaszczyk (eds) (1996). Translation and Meaning, part 3. Proceedings of the Maastricht Session of the 1st International Maastricht-Lodz Duo Colloquium on "Translation and Meaning", Held in the Netherlands, 19-22 April 1995. Maastricht: Hogeschool Maastricht, School of Translation and Interpreting, 482-495.

Mason, Kirsten (1982). "Metaphor and Translation.” Babel 28, 140-149.

Mounin, Georges (1963). Les problèmes théoriques de la traduction. Paris: Gallimard.

Newmark, Peter (1985). "The Translation of Metaphor." René Dirven \& Wolf Paprotté (eds) (1985). The Ubiquity of Metaphor. Amsterdam/Philadelphia: John Benjamins.

Nida, Eugene (1964). Towards a Science of Translating. Leiden: E.J. Brill.

Stienstra, Nelly (1993). YHWH is the Husband of his People. Analysis of a Biblical Metaphor with Special Reference to Translation. Holland: Kok Pharos.

Tabakowska, Elzbieta (1993). Cognitive Linguistics and the Poetics of Translation. Tübingen: Günther Narr.

My thesis (MA-thesis, 100 pages) was completed in April 2001. It is entitled Metaphor and Translation - a comparative study of two Danish Translations of Federico García Lorca's "Poeta en Nueva York". Institute for Romance Language and Literature, Spanish Department, University of Aarhus, Denmark.

${ }^{1}$ There are two first editions; The Poet in New York and Other Poems, edited by W.W Norton (New York), and Poeta en Nueva York, edited by José Bergamín (Mexico), both 1940.

${ }^{2}$ Cf.Lakoff \& Turner 's index of metaphors in Lakoff \& Turner 1989:222.

${ }^{3}$ Idem 221

${ }^{4}$ Idem 221

${ }^{5}$ Idem 223

${ }^{6}$ Idem 223

${ }^{7}$ Idem 222 